\title{
IPTEKS PENGENDALIAN INTERNAL TERHADAP ASET TETAP PADA PT JASA RAHARJA (PERSERO) CABANG SULAWESI UTARA
}

\author{
Elly Herawati ${ }^{1}$, Rachaya M. Mokoginta ${ }^{2}$, Christian Datu ${ }^{3}$ \\ 1,2,3 Jurusan Akuntansi, Fakultas Ekonomi dan Bisnis Universitas Sam Ratulangi, Jl. Kampus Unsrat, Manado, \\ 95115, Indonesia
}

Email : Ellyherawati771@gmail.com

\begin{abstract}
PT JASA RAHARJA (Persero) branch North Sulawesi is a branch office from PT JASA RAHARJA (Persero) and this company is one of state-owned enterprises which engaged in social insurance, especially for accident insurance and compensation insurance. In running every operational activity, every company surely must have fixed assets, be it in the form of buildings, office equipment, vehicles and so which can support employee performance. Fixed asset in a company must be secured in many ways of surveillance, control over costs incurred to get the said fixed asset, provide asset number so it will be easier to review the useful life of each asset, and whether said asset still can support employees performance or not. In this case, it is very important for us to pay attention to its internal control, because based on a research we did during our internship in PT JASA RAHARJA (Persero) branch North Sulawesi, each asset's internal control from the company need to be more efficient in terms of the element of the environment control, activities of control, related information on fixed asset and monitoring that has been done before to do physical matching of fixed asset, and appropriate allocation based on its function and responsibilities. Then, the company must pay attention to expenditures of income and expenses on fixed asset, by following insurance for fixed assets, make an audit committee, and implement the disposal and elimination of fixed asset. Suggestions for company to improve employees performance, through increasing exploration of knowledge and functions of application in order for employee to use it effectively and for presentation statement and efficiency of information about company's fixed assets more reliable and accurate.
\end{abstract}

Keyword : internal control, fixed asset, Insurance

\section{PENDAHULUAN}

Tujuan dari perusahaan yaitu proses menjaga kesinambungan perusahaan dalam jangka panjang. Maka dalam menjalankan kegiatan usaha perusahaan harus meningkatkan Nilai perusahaan dengan cara meningkatkan kinerja keuangan, mengurangi resiko yang merugikan yang di sebabkan oleh tindakan pengelola yang cenderung menguntungkan diri sendiri, serta dapat meningkatkan kepercayaan masyarakat. Badan usaha juga perlu melakukan pengadaan untuk aset tetap secara cepat, fleksibel, efisien, dan efektif agar dapat memenuhi kebutuhan perusahaan dengan tepat sehingga perlu memperhatikan prinsip-prinsip efisien, efektif, transparan, adil dan wajar. Perusahaan memerlukan Aset Tetap seperti kendaraan, peralatan dan perabotan perusahaan, mesin-mesin, dan gedung. Dalam masa manfaatnya Aset Tetap Biasanya lebih dari satu tahun/satu periode akuntansi dan akan disusutkan pada akhir periode Akuntansi dan Aset Tetap tersebut yang digunakan untuk kegiatan operasional perusahaan. Maka perusahaan perlu adanya pengendalian internal yang dimana bertujuan untuk menjaga keamanan Aset Tetap milik perusahaan, dan perlu juga memeriksa ketelitian dan kebenaran data akuntansi secara cepat.

Dalam proses penyajian Aset Tetap perlu adanya pengendalian. Yang dimana pengendalian internal dapat membantu perusahan dalam mengontrol pengeluaran terhadap 
biaya yang dikeluarkan guna untuk memperoleh Aset Tetap, dan mengukur masa manfaat dari Aset Tetap guna meningkatkan efisiensi operasional Perusahaan. PT Jasa Raharja (Persero) Cabang Sulawesi Utara merupakan badan usaha yang bergerak dibidang asuransi kecelakaan, tentunya perusahaan tersebut perlu memiliki Aset Tetap. Salah satu cara untuk mengamankan dan mengontrol Aset Tetap adalah dengan adannya pengendalian internal.

\section{TINJAUAN PUSTAKA}

Menurut Lembaga - Lembaga sebagai Penanggung Jawab Sistem Pengendalian Internal dapat didefinisikan Pengendalian Internal merupakan Proses yang dipengaruhi oleh dewan direksi, manajemen dan pegawai, serta untuk memberikan jaminan yang layak guna mencapai tujuan - tujuan dari seg efektivitas dan efisiensi operasi, dapat dipercayannya pelaporan keuangan, dan kepatuhan peraturan dan hukum yang berlaku.

COSO 2013 merupakan Transisi dari COSO 1992 Framework serta dalam perubahaannya melalui lima langkah dan salah satu cara untuk menavigasi transisi ini perlu untuk mengembangkan kesadaran, keahlian dan keselarasan sehingga framework ini dapat membangun kesadaran internal. Lingkungan Pengendalian, Penilaian Resiko, Aktifitas Pengendalian, Informasi dan Komunikasi, Aktivitas Pemantauan.

Aset Tetap menurut ED PSAK 16 Tentatng Aset Tetap, Maka Aset Tetap dapat didefinisikan sebagai Aset Berwujud yang dimiliki dan digunakan dalam produksi dan penyediaan barang dan jasa, untuk direntalkan kepada pihak lain atau untuk tujuan administratif dan diharapkan digunakan selama lebih dari satu periode.

Perancangan Pengujian Pengendalian Internal Terdapat beberapa jenis pengujian pengendalian internal yang dapat di pilih oleh auditor dalam pelaksanaan pengujian pengendalian internal yakni Permintaan Keterangan,Pengamatan, Inpeksi, Pelaksanaan kembali.

\section{METODE DAN TEKNIK PENERAPAN IPTEKS}

\subsection{Metode Penerapan Ipteks}

Metode Ipteks yang akan diterapkan yaitu mengimplementasikan pengendalian internal berdasarkan Komponen Pengendalian Internal terhadap aktiva tetap yang efektif menurut COSO Internal Control-Integrated Framework 2013 pada PT Jasa Raharja (Persero) Cabang Sulawesi Utara.

\subsection{Teknik Penerapan Ipteks}

Teknik Penerapan Ipteks yang digunakan adalah melakukan pengamatan serta ikut membantu dalam menjalankan seluruh komponen pengendalian internal terhadap aktiva tetap yang efektif menurut COSO Internal Control-integrated Framework 2013 yang terdiri dari lima yakni : (1) Lingkungan Pengendalian; (2) Penilaian Resiko; (3) Aktivitas Pengendalian; (4) Informasi dan Komunikasi; (5) Aktivitas Pemantauan.

\section{PEMBAHASAN}

\subsection{Gambaran Objek Penerapan Ipteks}

PP No. 8 Tahun 1965, pada tahun 1965 dibentuklah badan hukum dengan nama “ Perusahaan Negara Asuransi Kerugia Djasa Rahardja". Perusahaan ini bertugas atas mengelolaan UU No. 33 Tahun 1964 "Dana Pertanggungan Wajib Kecelakaan Penumpang Darat, Laut dan Udara" dan UU No. 34 Tahun 1964 "Dana Kecelakaan Lalu Lintas Jalan". PT Jasa Raharja merupakan perusahaan asuransi yang bergerak dibidang Asuransi Sosial terkhusus untuk menangani penyantunan korban dari kecelakaan lalu lintas baik di darat, laut dan udara. Pada tahun 1970 tugas dari PNAK Jasa Raharja semakin berat sehingga dikeluarkannya Surat Keputusan Menkeu RI No.Kep/750/KMK/IV/II/1970 dalam Surat Keputusan Tersebut status dari PNAK Jasa Raharja berubah Menjadi Perusahaan Umum 
(Perum) Jasa Raharja. Tahun 1980 dikeluarkan PP No.39 1980, mengubah status Perum menjadi perusahaan perseroan (Persero) dengan nama PT Jasa Raharja. Kemudian dikukuhkan setelah dilakuakan beberapa kali perubahan dan pada tanggal 1 Agustus 2012 yang dibuat dihadapan Julius Purnawan SH., M.Si., Notaris di Jakarta. PT Jasa Raharja saat ini terdiri dari 1 Kantor Pusat 29 kantor cabang, 63 kantor perwakilan, 62 kantor pelayanan Jasa Raharja (KPJR) dan 1825 kantor Pelayanan Bersama samsat yang tersebar di seluruh Ibukota Provinsi dan Kota/Kabupaten dan PT Jasa Raharja (Persero) Cabang Sulawesi Utara di resmikan tanggal 3 april 1989 oleh Gubernur KDH Tingkat I Sulawesi Utara C.J Rantung.

\section{Pengendalian Internal Aktiva Tetap Pada PT Jasa Raharja (Persero) Cabang}

Sulut. PT Jasa Raharja (Persero) Cabang Sulawesi Utara memiliki struktur Berbentuk 4 Lini yaitu Bagian Operasional, Bagian Keuangan dan Akuntansi, Bagian SDM dan Umum,dan Bagian PKBL. Dalam kegiatan pengelolahan Aset Tetap dilaksanakan oleh bagian SDM dan Umum (khusus diatur oleh PA Umum). Untuk melakukan pengadaan Aset Tetap ditangani oleh PA Umum dan di Otorisasi Oleh Kepala Cabang, dan Penganggarannya oleh bagian Keuangan dan Akuntansi. Dalam Pengukuran Nilai Aset Tetap PT Jasa Raharja berdasarkan besaran harga perolehan atau bisa disebut dengan Metode Biaya Historis yang dimana Aktiva Tetap diukur sebesar harga perolehan Aktiva tersebut kemuadian dikurangi dengan Akumulasi penyusutan, metode penyusutan yang digunakan adalah metode garis lurus, dalam perbaikan aset tetap di otorisasi oleh bagian operasional dan kepala cabang. PT Jasa Raharja mengakui biaya pemeliharaan dan berbaikan sebagai beban. Dalam menghitung masa manfaat dari Aset Tetap, PT Jasa Raharja melakukan pengukuran sesuai dengan standart prosedur pengadaan barang/jasa yang dibuat oleh pihak Pusat dan untuk mempermudah perhintungan masa manfaat habis maka di setiap pengadaan Aset Tetap, Aset tetap yang dimiliki di beri label nomor dan tahun pengadaan. Namun walaupun sudah seperti itu masih saja sering terjadi hilangnya Aset Tetap dan adanya Aset tetap yang tidak berlabel sehingga pihak perusahaan sulit untuk mendata Aset Tersebut dan kasus ini sering terjadi pada KantorKantor Perwakilan.

\subsection{Pembahasan}

Pengendalian Internal yang efektif dan efisien berdasarkan COSO Internal Controlintegrated framework 2013 menyatakan bahwa 5 unsur pengendalian internal yang perlu dilaksanakan yakni :

Lingkungan Pengendalian, lingkungan pengendalian pada suatu organisasi,mempengaruhi kesadaran dari pihak yang berada didalamnya. Lingkungan yang mendasari pengendalian internal lainnya. Maka perusahaan perlu memenuhi faktor-faktor yang ada dalam lingkungan pengendalian yakni perlunya integritas, etika, serta mengembangkan kemampuan manajemen entitas dengan cara memberikan pelatihan terkait pengendalian internal Aset Tetap. Diperlukan juga filosofi menejemen dan gaya operasi agar dalam melaksanakan setiap kegiatan usaha dalam perusahaan orang-orang dalam entitas tersebut tidak berjalan sesuai dengan kemauannya tapi berdasakan filosofi dan gaya operasi yang ditentukan. Pentingnya Memanajemen dengan baik dalam hal menentukan wewenang dan tanggung jawab, pengorganisasian dan pengembangan orang-orang yang ada dalam entitas. Adanya kebijakan dan praktek sumber daya manusia untuk meningkatkan kemampuan pegawai. Perlunya perhatian dan arahan dari dewan direksi.

Penilaian Resiko, setiap entitas pasti akan dihadapkan dengan resiko baik dari pihak luar maupun dari dalam entitas itu sendiri tentunya resiko-resiko tersebut perlu ditaksir. Dalam melaksanakan Penilaian Resiko (Risk Assessment) sangat penting untuk menegakan tujuan, hubungan antara antara pegawai dan pihak manajemen teratas, dan konsistensi internalnya. Penilaian Resiko merupakan kegiatan identifikasi dan menganalisis resiko yang relevan dalam mencapai tujuan, sehingga dapat menentukan bagaimana resiko di tangani. Kondisi yang dapat mempengaruhi terjadinya resiko yakni perekonomi, perindustri, regulasi 
dan pengoperasian yang selalu berubah-ubah, sehingga sangat perlu adanya mekanisme yang baik untuk dalam kegiatan identifikasi dan menghadapi resiko khususnya terkait dengan kondisi tersebut.

Aktivitas Pengendalian, merupakan Kebijakan dan Prosedur yang membantu meyakinkan menejemen bahwa arahan telah dilaksanakan dan membantu meyakinkan bahwa tindakan yang diambil telah tepat untuk menghadapi resiko sehingga tujuan dari entitas dapat tercapai dengan baik. Aktivitas Pengendalian diterapkan pada seluruh aspek dalam perusahaan. Aktivitas Pengendalian yang ada pada perusahaan perlu dikontrol sesuai level dan fungsi sesuai dengan kegiatan yang dilaksakan dan biasanya dalam bentuk Persetujuan, Otorisasi, Verifikasi, Rekonsiliasi, Review terhadap Perfoma Operasi, Pengaman Aset, dan Pemisahan Tugas, hal-hal tersebut memerlukan pengendalian agar resiko-resiko yang akan terjadi dapat ditangani dengan mudah karna telah berjalan sesuai dengan kebijakan dan prosedur yang ditetapkan.

Informasi dan Komunikasi, dalam melaksanakan setiap kegiatannya entitas perlu adanya Informasi dan Komunikasi agar dalam penyampaian tugas dan pencapaian tujuan dapat berjalan dengan baik, dan informasi yang didapat perlu mudah dipahami, dan terkomunikasikan dalam frametime yang memungkinkan pihak yang menjalankannya sesuai dengan prosedur. Jika informasi dan komunikasi berjalan dengan baik maka segala sesuatu yang berhubungan dengan manajemen internal terkait dengan laporan keuangan, operasional dan sistem dapat berjalan sebagaimana mestinya, dalam mencapai tujuan. Tidak hanya di sajikan dalam bentuk data-data internal saja tapi juga terjadi dalam kegiatan eksternal dimana biasanya terjadi saat pengambilan keputusan bisnis dan laporan untuk pihak eksternal. Komunikasi perlu juga memiliki lingkup yang luas, tersebar diseluruh aspek perusahaan. Semua yang terlibat dalam perusahaan harus menerima informasi yang disebarkan oleh menejemen teratas dengan baik bahwa setiap pengendalian tanggung jawab diambil dengan serius, setiap orang yang terlibat dalam perusahaan perlu memahami peran setiap pihak dalam SPI, seperti mereka memahami hubungan pekerjaan mereka dengan pekerjaan orang lain. Selain menerima informasi dari pihak menejemen teratas, perlu juga adanya informasi dari bagian terbawah hingga bagian teratas agar dapat berkomunikasi dengan signifikan kepada atasan, dan juga mampu menjalin komunikasi dengan stakeholder perusahaan.

Pemantauan, setiap SPI perlu diawasi, karena dalam menentukan peningkatan dari perfoma sistem setiap waktu. Melalui pemantauan yang rutin dan sesuai alur, pengevaluasi yang dilakukan dari keduanya, dapat dilihat proses telah diselesaikan atau tidak. Kegiatan tersebut termasuk menejemen dan supervise yang regular dan kegiatan lainnya yang dilakukan oleh setiap individu dalam perusahaan dalam menjalankan pekerjaan. Luas dari evaluasi terpisah, tergantung dari perkiraan resiko dan keefektifisan prosedur pengendalian yang sedang berlangsung. Proses dan hasil dari pengendalian internal perlu dilaporkan pada pimpinan, beserta masalah yang serius juga perlu dilaporkan kepada menejemen teratas dan dewan direksi.

\section{KESIMPULAN DAN SARAN}

\subsection{Kesimpulan}

Pengendalian Internal terhadap Aset Tetap pada PT Jasa Raharja (Persero) Cabang Sulawesi Utara saat ini sudah cukup baik, namun akan berjalan dengan efektif dan efisien apabila tiap komponen dalam COSO Internal Control-integrated framework dilaksanakan sesuai dengan alur dan diterapkan secara menyeluruh dalam Perusahaan.

\subsection{Saran}

Dalam hal menjaga keamanan dan efektifitas serta efisiensi dari Aset Tetap sangat penting bagi Perusahaan untuk lebih Intens lagi dalam pengecekan Aset Tetap yang dimiliki baik di perusahaan Cabang Maupun Perwakilan agar dapat mengurangi Aset Tetap yang 
Tidak Berlabel atau Hilang. Memberikan pelatihan dan memperluas pengetahuan para pegawai terutama pengetahuan Sistem pengendalian Internal atas Aset Tetap yang dimiliki perusahaan.

\section{DAFTAR PUSTAKA}

Cahyadi, AI. 2013 Pengujian Pengendalian Aktiva Tetap Dalam Mendeteksi Kehilangan Aktiva Tetap

Gerlinas, Ulric J, et all. 2005 Accounting Information system. Chapter 9. $6^{\text {th }}$ edition. South Western Collage Publishing

IAI, 2016 ED PSAK 16 Tentang Aset Tetap Penyesuaian

KPMG LLPA. 2013 a Canadian limited liability partnership and a member of KPMG International about COSO Internal Control - Integrated Framework

Jasella Lourina Makaluas, Winston Pontoh Pengendalian Intern Aset Tetap PT. Lumbung Berkat Indonesia

Dian, PL. 20145 Komponen Sistem Pengendalian Internal Menurut COSO

PT Jasa Raharja (Persero). 2014. Tata Kelola : Tujuan Perusahaan

Surat Keputusan Direksi No. KEP/55/2017 Tentang Perubahan Surat Keputusan Direksi No. KEP/15/2012 Tentang Pedoman Akuntansi Keuangan dan Standar Prosedur Operasi Akuntansi Keuangan PT Jasa Raharja

Surat Keptusan Direksi No. KEP/84/2014 Tentang Revisi Surat Keputusan Direksi No. KEP/14/2012 Tentang Standar Prosedur Operasi Pengadaan Barang atau Jasa

PT Jasa Raharja (Persero). 2011 Buku 50 Tahun PT Jasa Raharaja (Persero) Tentang Jalan Panjang Melayani

Cindy Wijaya. Pemeriksaan Operasional Untuk Meningkatkan efektifitas dan efisiensi Pengelolaan Aset Tetap 